\title{
The Paradox Of Faculty Development
}

\author{
Robert L. Minter, Ph.D., Walsh College, USA
}

\begin{abstract}
This paper explores the weaknesses in university faculty development efforts when compared with corporate professional development practices. Suggestions are offered to think of faculty development as a process rather than as isolated development activities.
\end{abstract}

Keywords: University faculty development contrasted with corporate professional development

\section{INTRODUCTION}

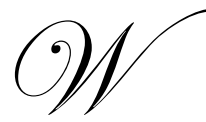

hat are the issues facing universities in their attempts to support faculty development as a process rather than as isolated educational events that are provided for faculty? This author has spent over thirty years working full time both in the corporate sector and also as a full-time professor and university administrator. Being responsible as a change agent for corporate development, this author has become sensitive to the fact that organizational change cannot be successful without having an effective process for professional development, training, and succession planning.

Having served as Dean of several colleges of business and as an Executive Vice President and Chief Academic Officer of a large graduate business college, the author has become very sensitive to what a college faces when trying to introduce change in the academic environment and the associated faculty development issues that accompany the change efforts.

\section{NEED FOR FACULTY DEVELOPMENT}

As universities move into the twenty-first century, they will be finding more accountabilities placed upon them by the public, students, accreditation agencies and employers to justify the costs of higher education and quality of education being delivered. Consequently, strategic planning for faculty development, effective implementation and outcomes assessment of the development process are extremely important for universities to demonstrate and be accountable for best practices.

Critics of higher education within the past twenty-to-thirty years point out the need for improvement in university teaching practices and faculty development. There is a definite double standard, however, between what is required of elementary and secondary school teachers to be certified to teach and the lack of certification requirements for those who become university teachers. ${ }^{1}$

A major fallacious assumption of higher education hiring practices within the United States and globally is that if one has a graduate degree from an accredited institution, the individual is qualified to teach. Imbedded in this assumption is that the more alphabet designators after one's name, the more qualified the individual becomes. University faculty hired under such an assumption is not only unfair to the unsuspecting consumer, but is operating on the edge of unethical practice.

\section{Corporate vs. Academic Professional Development}

Corporate sector and universities are usually far apart when providing professional development opportunities to support strategic change efforts. The corporate sector is often more organized, more sophisticated, and more supportive with budget initiatives to develop its human resource capitol than what exists within 
universities. Evidence suggests that universities are not performing well in establishing effective faculty development initiatives to improve the quality of instruction. ${ }^{2}$

It would be difficult to find a university that did not allude to faculty development in its strategic plan. To exclude such a concept would be non-collegial, irreverent, and politically not correct. Even though faculty development is a "household" word in collegiate settings, it has also become an illusive practice. The word "development" connotes that a "process" is involved within the institution to assist individuals through evolutionary stages of professional maturation. Upon close examination of many university approaches to faculty development, one will quickly discover a lack of "process." The more common approach among universities is to support faculty to attend isolated activities (e.g., workshops/conferences) that lack a symbiotic relationship.

\section{FACULTY DEVELOPMENT: CONTINUUM VIEWPOINT}

University approaches to faculty development can be illustrated on the following continuum:

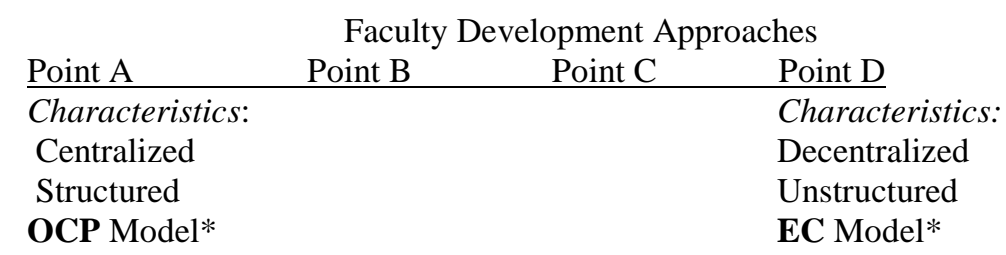

The above continuum assumes that Point A approaches represent an ideal form of planned, well organized, and fiscally supported professional development processes that nurture positive outcomes for both the human capital and health of the university. As one move along the continuum to Point $\mathrm{D}$, universities will exhibit less structure, less budget support, less impact on the professional development of faculty and few positive outcomes demonstrated in the development of its faculty and competitive stature of the organization.

Point A approaches are centralized, are usually well managed and staffed with at least a full-time director. Major responsibilities of the director are to identify faculty development needs, establish programs to meet these needs, coordinate professional development activities across campus, and assess the outcomes for the university. The typical configuration of a faculty development center under this approach will have its own budget and will provide dedicated office space for the director and secretarial/staff support.

At Point B, the budgeted "center" will probably operate out of a designated faculty member's office. Under this approach, the director will coordinate university faculty development activities on a part-time basis, will teach classes on a reduced load agreement, and will manage a modest budget to provide financial support for development of faculty. The director will engage in minor assessment of expected outcomes. Much of the professional development activity under this approach represents a combination of semi- planned and ad hoc efforts to address the growth needs of faculty. The Point B professional development administrator position contains less leadership empowerment to provide effective development efforts than one will find under the Point A approach.

At Point $\mathrm{C}$ of the continuum, the major responsibility for faculty development may be totally or quasi-decentralized within the responsibilities of dean or department chairs and is loosely related to university strategic planning activity. A majority of the budget support for the center at this point on the continuum is usually dependent upon the funds generated for faculty development out of the dean and/or department budget initiatives.

At Point $\mathrm{D}$ of the continuum, the faculty member is totally on his/her own to second guess the system, and takes full responsibility to pursue one's intellectual and professional growth with little or no relationship to the university's strategic plan. Budget support is meager at this juncture.

*OCP $=$ Organizational-Centered Process Model; EC= Ego-centered Model 
For many universities, resources provided for faculty development at any point along the continuum are at best minimal. One would think, however, that the more institutionalized the process is (Points A \& B), the more university budget support would be available for faculty development than at Points C and D. This, however, is also a shaky assumption.

\section{Common Faculty Development Practices:}

Wherever the "center" is along the continuum just described, faculty development activities are often not process based and only support isolated activities for the faculty member such as: professional leave, professional travel, sponsored research awards, seed money to develop projects or pursue a meritorious professional agenda, grants-in-aid, support to sponsor guest speakers, workshops, conferences and temporary faculty exchanges.

Common topics utilized in faculty development workshop or conference formats are frequently short term attempts to engage and enlighten faculty. Typical workshop/conference themes are: grant writing, student learning styles, working with the adult learner, testing and grading, preparing a syllabus and software instruction. Some scheduled meetings may include opportunities for faculty to share their research and scholarship with colleagues.

The reality is that the majority of U.S. universities are operating under tight budgets, especially the medium to small size campuses. Where there are insufficient budgets and leadership dedicated to professional development, one will find pseudo-attempts to establish faculty development processes. Pseudo attempts can be observed anywhere along the continuum from Points A through D. With the downturn in the economy, as with the corporate sector, one of the first areas to be cut in the university budget is support for employee training and faculty development. Under these conditions, faculty development becomes an oxymoron in its own right.

It is ironic that the goal of universities is to educate and transfer knowledge to its students and to create new knowledge through encouraging faculty scholarship; the same goal does not seem operative within the "halls of Ivey" to support a continuous process for faculty development. Unfortunately, faculty development often turns into a sideline activity at the institutional level. This paradox/contradiction becomes clearly apparent if one is dedicated to establishing a "learning organization" as proposed by Senge. ${ }^{3}$

\section{PROFESSIONAL DEVELOPMENT MODELS: CORPORATE AND ACADEMIC}

\section{Corporate Model}

To understand infrastructure issues that relate to faculty development as a process, one needs to look at many of the Fortune corporations that have become relatively sophisticated in establishing professional development processes within their own organizations.

Two models are proposed to better understand the dynamics of professional development. The Organizational Centered Process Model (OCPM) is usually more common in for-profit, medium to large size corporations where employee development is designed more as a process than as isolated development activities such as is the case in higher education. The OCPM provides both planned lateral and vertical development opportunities for the corporate employee.

Operating under the OCPM model, corporate development opportunities not only exist within the department of one's employment, but also transcend to other corporate opportunities outside one's home department. Inherent in the OCPM is the initiative and budget for employee development that begins with the firm's strategic succession planning in developing employee potential.

Corporate career development opportunities (both vertical and lateral) are often time- bound organized activities that prepare one for the next career experience within the firm. Transfers between organizational units in the business sector are often encouraged. Unlike academia, many corporations engage in succession planning, coaching and mentoring of their high potentials. Included in this process are opportunities for internal and cross training experiences for those earmarked as backups when the earmarked position is vacated. 


\section{Academic Model}

In contrast, within university settings there is a rigid, time bound vertical promotion system for faculty that is established on an Ego-Centric Model (ECM). This model places most of the professional development responsibilities and costs for development on the shoulders of the faculty member (Points C and D on the continuum described earlier). Faculty generally create their own development plans without having to confer with the institution. For example, faculty:

- $\quad$ often pursue their individual research and scholarship interests;

- $\quad$ have few (if any) approved professional development goals;

- $\quad$ decide what conferences they will attend;

- $\quad$ are more loyal to their professional ambitions than to the university;

- do not have to be too concerned about the synergy between their professional self-interests and their fit with university goals and objectives.

For the most part, faculty must rely on obtaining grants or subsidizing their own scholarship activity. The university may help somewhat, but the burden is primarily on the shoulders of the faculty member. There is literally no strategic planning taking place in most academic institutions when it comes to developing their human capitol under the ECM approach.

After entering academia, faculty quickly learn that vertical career opportunities are limited and lateral promotion within the university setting is almost nonexistent. For those who want to pursue academic administrative careers, faculty will find opportunities are extremely limited within one's own institution. Pursuing administrative career opportunities often means one will have to look to other universities for these professional vertical progressions. Internal coaching and mentoring to become an administrator is usually nonexistent in universities for the aspiring college administer. One often becomes a university or college administrator by being opportunistic with a willingness to be flexible and mobile in order to experience administrative career progressions. The learning curve for college administrators is usually composed of trial and error experiences, with little (if any) opportunity to be coached or mentored.

From the initial entry point of becoming an assistant professor, a faculty member will be required to serve in this rank for approximately five to six years before being considered eligible for the associate professor level. Assuming the assistant professor meets all the institutional criteria for becoming an associate professor with tenure, he/she will remain in the associate professor rank for approximately another five to six years before becoming eligible for promotion to full professor.

So, after serving for approximately ten-to-twelve years as both an assistant and associate professor, achieving the rank of full professor becomes the final promotion opportunity in the vertical career ladder of a faculty member. Some may consider this as a glass ceiling or dead-end promotional path that one can reach within slightly less than a dozen years. In academia, promotion to each of these ranks usually carries with it a promotional salary increase. Depending on the university and union contract one is working under, typically a $\$ 2,000$ to $\$ 6,000$ salary increase is provided as a promotional award. Continuing this scenario, a faculty member who is hired as an assistant professor, and is promoted to associate and then full professor, will receive a total promotional salary increase ranging from $\$ 4,000$ to $\$ 12,000$ for the decade or more it takes to progress to the upper professorial ranks.

These promotional increases are, of course, in addition to any across- the-board annual salary increases given to faculty by the university. If annual salary increases are given to faculty, they can range anywhere from $2 \%$ to $4 \%$, with the average generally being $3 \%$.

\section{Major Contrasts between Corporate and Academic Models}

- $\quad$ Corporations provide more lucrative promotional awards, perks, and/ or salary increases as one progresses through the firm. 
- $\quad$ Corporations who are focused on employee and professional development provide career diagnostics and career counseling opportunities for their employees. This practice in universities settings is extremely rare.

- Corporations have more of a tendency to provide coaching and mentoring opportunities for their professional management team. Although coaching and mentoring concepts are discussed in academia for junior and senior level faculty, seldom is a process put into place to accomplish these ends.

- Weaknesses in the development and promotional support for faculty are seldom addressed by the academy. It is very difficult to find a university that can be recognized as a model of "best practices" that fit with the OCPM to support professional development as a process.

\section{Issue of "Best Practices"}

The question will arise as to what are the elements that compose "best practices" in establishing an OCP process for faculty and professional development? In addressing this question the following basic, centralized organization of developmental practices will be necessary:

- $\quad$ Establish a Faculty Development Center with full-time leadership. The Center's director should report either to the vice president of academic affairs or to the university's president.

- $\quad$ Establish professional development plans for all full-time faculty, pushing the responsibility for plan development and implementation to individual academic units. Plans should be monitored by the center's director to determine if they support the strategic plans of the academic department and the university

- $\quad$ Support and encourage faculty and administrative succession planning with appropriate learning experiences identified that will permit universities to "grow their own" future leaders.

- Provide university budget support to maintain professional personnel to oversee and coordinate professional development processes. These individuals should provide vision to help guide and coordinate development activities.

- $\quad$ Require faculty to submit annual scholarship and development plans that are related to annual performance reviews. Plans submitted should identify what department and institutional strategic goals are being supported by each faculty member's development plan.

- $\quad$ Develop an award system to encourage and motivate faculty in order to sustain the momentum for change.

- Conduct annual training and development needs assessment. The university should then design developmental experiences for faculty, provide budget support, and assess their progress as part of their overall performance reviews. Performance reviews should be based on a 360 degree model.

- $\quad$ Design professional development opportunities within the university that provide vertical, lateral and crosstraining development experiences for faculty.

- $\quad$ Assist units within the university to establish best practices for faculty development and scholarship.

- $\quad$ Establish an organized coaching process for junior faculty (both at assistant/associate level ranks) who have not yet attained full-professor status.

- $\quad$ Establish a post tenure performance review process for tenured full professors and relate outcomes to identify future development needs.

- $\quad$ Conduct annual faculty development surveys to identify professional enrichment experiences/opportunities desired by faculty.

- $\quad$ Efforts to redesign other organizational units should consider dotted line relationships with the professional development Center's director, such as the university's grant writing director, human resource director, and union officer (if a union exists on campus).

The above is by no means to be considered all inclusive in the establishment of a university process for faculty development. Many more ideas can be included by engaging both administrators and faculty in the development of the process and in the design of outcome measures.

\section{CONCLUSION}

Higher Education institutions, as learning organizations, need to establish faculty development processes to equal or surpass the model used by corporations who have had success in this area. 
The professional development of faculty is key to building successful academic experiences for students, faculty and for the university in developing its competitive edge and uniqueness in the marketplace of higher education.

\section{Footnotes}

${ }^{1}$ Osgood, A., \& York, P. (1992). Faculty teacher training at the post-secondary level (ERIC document number ED362511).

${ }^{2}$ Gullatt, David \& Weaver, Sue Wells. "Use of faculty development activities to improve the effectiveness of U.S. institutions of higher education." Paper presented at the Annual Meeting of the Professional and Organizational Development Network of Higher Education, $22^{\text {nd }}$ Conference, October 16-19, 1997.

${ }^{3}$ Senge, P.M. (1990) The fifth discipline: The art and practice of the learning organization. New York: Doubleday. 